\title{
Distribution and behaviour of meiofaunal copepods inside and outside seagrass beds
}

\author{
Geoffrey R. F. Hicks
}

National Museum of New Zealand, Private Bag, Wellington, New Zealand

\begin{abstract}
The abundance and species composition of meiobenthic copepods from blades and subcanopy sediments of seagrass Zostera capricorni beds has been compared with adjacent unvegetated sediment banks in Pauatahanui Inlet, New Zealand. A range of sampling protocols has established that abundance on blades and on sediments beneath dense growths of Zostera is significantly higher than on nearby bare sand substrata. Further away from beds abundance increases to a level approximating that of seagrass beds when individuals on blades and subcanopy sediments are taken together. Species richness is nearly twice as high on blades as on sedimentary substrata either inside or outside beds, although in general there is no close association between abundance or species richness and the surface area of individual Zostera blades. Multiple pairwise comparisons of numbers of individuals and species sampled over 4 independent $24 \mathrm{~h}$ periods at both high and low tide, day and night, demonstrate that significantly more individuals and species occur on Zostera blades at low tide than at high tide irrespective of light regime. In contrast, those on subcanopy sediments show no such tidal variability in abundance. Day or night there are more species on blades than on sediments irrespective of tidal state. Reductions in faunal abundance during high water suggested a migratory behaviour coincident with tidal inundation. Experimentally emplaced emergence traps confirmed that a substantial proportion of the Zostera bed copepod fauna actively swim into the water column during high water, explaining the reductions in abundance found when sampling blades and sediments alone. Significantly more copepods enter traps emplaced over Zostera beds compared with unvegetated sites. Over $70 \%$ of the trapped fauna is derived from blades or as phytal itinerants, establishing an important difference between copepod faunas from vegetated and unvegetated habitats. An earlier view that the appearance of meiofaunal copepods in the water column was due primarily to passive hydrodynamic resuspension needs revision in the light of pronounced swimming activities amongst seagrass inhabitants. Observations on fish predators in seagrass systems were made and the ecological implications of active benthic-pelagic exchanges of seagrass copepods are discussed.
\end{abstract}

\section{INTRODUCTION}

In recent years, there has been a surge of interest in the faunal composition and ecology of invertebrates inhabiting seagrass beds, with most studies being centred in tropical systems dominated by Thalassia, Halodule and Syringodium. In more temperate regions of N. America, Europe and Australasia, work is in progress in grassbeds dominated by Zostera and Posidonia and there is now a substantial literature concerning the determinants of macrobenthic species abundance, composition and diversity in these habitats (see Heck \& Orth 1980, Lewis 1984, Summerson \& Peterson 1984 for a summary of pertinent references). The impetus for such research effort has largely been based upon a recognition of the role seagrass beds play in the energy or trophic status of estuarine systems, either through their release of dissolved organic carbon directly into the water column (Penhale \& Smith 1977), or, after defoliation and fragmentation of leaves, by contributing to the detritus pool (Mann 1972). Moreover, the use of seagrass beds as nursery and feeding areas for the young of many commercially important fish species has added to the presumed importance of vegetated habitats in estuaries (see Pollard 1984).

Despite the plethora of investigations concerning macrofauna in seagrass habitats, there are few involving components of the meiobenthos. Studies on seagrass meiofauna have largely been descriptive (see Bell et al. 1984 for review), and only recently (e.g. Robichaux et al. 1981, Novak 1982, 1984, Sogard 1984, Thistle et al. 1984, Decho et al. 1985) have attempts been made to more critically evaluate some of the 
causative factors to pattern and composition of grassbed meiofaunal populations. Thistle et al. (1984), for example, concluded that the structural imposition to sandflats of Syringodium plants had the effect of creating localized patches of increased sediment bacterial activity. It is believed that these patches act as attractants to, and therefore enhance the abundance of, bactivorous harpacticoid copepods. Sogard (1984) demonstrated that while meiofaunal harpacticoids from seagrass habitats comprised by far the dominant fraction of the diet of a grassbed fish, predation by this animal did not significantly affect the population dynamics of copepod prey. This finding supports similar conclusions from studies conducted in unvegetated habitats (Alheit \& Scheibel 1982, Hicks 1984, 1985b, Gee et al. 1985).

In order to confirm the universality, or otherwise, of some of the patterns exposed during studies of macrobenthic organisms, especially crustaceans (e.g. Stoner 1983, Lewis 1984), the copepod fauna (primarily harpacticoids) associated with Zostera capricorni Aschers. beds has been compared with adjacent unvegetated sediment banks. Preliminary tidal and diel sampling has also presented a new view on the behaviour of the residents of grassbeds compared with their bare sand counterparts. Observations on predatory fishes in this environment add to our understanding of seagrass beds as refuges from predation.

\section{MATERIALS AND METHODS}

Study site. Four sampling stations for sediment and one for seagrass blades were established on an intertidal fine sand bank (Mana Bank) in Pauatahanui Inlet, the eastern arm of Porirua Harbour, Wellington, New Zealand $\left(41^{\circ} 06^{\prime} \mathrm{S}, 174^{\circ} 54^{\prime} \mathrm{E}\right)$. Tidal sea level change within the inlet is semidiurnal and near symmetrical, with mean spring range $1.25 \mathrm{~m}$ and mean neap range $0.4 \mathrm{~m}$ (Read 1984). Local sea level and tidal range are commonly influenced by ambient meteorological conditions (pers. obs.). Salinity and temperature values are typically within an annual 17 to $34 \%$ and 7 to $25^{\circ} \mathrm{C}$, respectively (Hicks 1984).
Station 1 was located amongst fine sand surface ripples, a site detailed elsewhere (Hicks 1984). Station 2 was positioned some $150 \mathrm{~m}$ east on open unvegetated fine sand with a featureless surface microtopography. Station 3 was from sand areas between sparsely occurring plants in monotypic stands of the rhizomatous eelgrass Zostera capricorni. Station 4 was $15 \mathrm{~m}$ further east from small (subcanopy) sand areas amongst plants in a dense bed of Zostera. Plant densities at $\operatorname{Stn} 4$ were roughly 10 times that at $\operatorname{Stn} 3$ (Table 1). Samples of eelgrass blades were taken in dense Zostera adjacent to Stn 4, and will henceforth be referred to as Stn 5. At low tide, water drains from the beds, but ponding in depressions amongst the seagrass occurs and it is from the margins of such shallow depressions that blades were sampled. Water depth over these sites at MHWS is about $1.2 \mathrm{~m}$.

According to Healy (1980, p. 138), above-ground biomass of Zostera in Pauatahanui is lost in winter. On the contrary, my observations spanning $3 \mathrm{yr}$ confirm that it is a perennial at this locality. Seasonal defoliation and blade fragmentation occurs to some degree in winter but does not lead to complete wastage of above ground structures (Table 1). Blades average 127.61 $\pm 26.23 \mathrm{~mm}$ long with a near uniform width of 2.81 $\pm 0.37 \mathrm{~mm}$ ( $n=125$ in both cases), tapering only slightly apically.

Unlike many of the tropical seagrass species (Heck 1979, Lewis \& Hollingworth 1982), Zostera in Pauatahanui Inlet does not support large and diverse assemblages of macroalgae growing epiphytically on the blades. Surface-borne bacteria and microalgae such as diatoms are, however, readily observed on Zostera as they are on other seagrasses (see Novak 1984).

Sampling. Copepods were collected from each substratum covering the 5 stations. Between 3 and 5 samples were taken during daylight hours at low tide at Stns 1 to 3, in December 1983, January, March and June 1984. Within the dense Zostera bed (Stns 4 \& 5), additional samples were made; sampling frequency, tidal and diel state, number and type of sample during each period are summarized in Table 2. Sediment samples at Stn 1 were taken from the troughs of sand

Table 1. Summer (February), winter (August) comparison of plant density and biomass between areas of sparse and dense seagrass stands, Pauatahanui Inlet

\begin{tabular}{|c|c|c|c|c|}
\hline \multirow[t]{2}{*}{ Zostera beds } & \multicolumn{2}{|c|}{$\begin{array}{c}\text { No. Zostera plants } \\
\mathrm{m}^{-2}(n=10)\end{array}$} & \multicolumn{2}{|c|}{$\begin{array}{c}\text { Biomass } \\
\left(\mathrm{g} \mathrm{m}^{-2}\right)(n=3)\end{array}$} \\
\hline & Summer & Winter & Summer & Winter \\
\hline Sparse & $48.31 \pm 21.4$ & $41.0 \pm 19.0$ & $3.93 \pm 0.61$ & $0.8 \pm 0.03$ \\
\hline Dense & $402.10 \pm 78.0$ & $370.0 \pm 48.0$ & $42.10 \pm 1.06$ & $29.03 \pm 0.58$ \\
\hline
\end{tabular}


Table 2. Summary of samples collected from dense Zostera bed 1982-1984. DS: sediment beneath plants; BP: clipped $10 \times 10 \mathrm{~cm}$ plot of blades; BI: individual blades; ET: emergence traps. $n=$ sample number. See text for sampling protocol

\begin{tabular}{|c|c|c|c|c|}
\hline Date & & Tidal state & Day/night & Sample (n) \\
\hline 15 Nov 1 & 1982 & Low & Day & $\mathrm{DS}(3), \mathrm{BP}(1)$ \\
\hline $20 \mathrm{Dec} 1$ & 1983 & Low & Day & $\mathrm{DS}(4), \mathrm{BP}(2)$ \\
\hline $20 \mathrm{Jan} \quad 1$ & 1983 & Low & Day & $\operatorname{DS}(3), \mathrm{BP}(2), \mathrm{BI}(10)$ \\
\hline $25 \operatorname{Jan} 1$ & 1984 & Low & Day & $\mathrm{BI}(10)$ \\
\hline $30 \mathrm{Jan} 1$ & 1984 & Low & Night & $\mathrm{DS}(6), \mathrm{BP}(1), \mathrm{BI}(10)$ \\
\hline 31 Jan 1 & 1984 & High & Day & $\mathrm{DS}(6), \mathrm{BP}(1), \mathrm{BI}(10)$ \\
\hline 31 Jan 1 & 1984 & High & Night & $\mathrm{DS}(6), \mathrm{BP}(1), \mathrm{BI}(10)$ \\
\hline $31 \mathrm{Jan} 1$ & 1984 & Low & Day & $\mathrm{DS}(6), \mathrm{BP}(1), \mathrm{BI}(10)$ \\
\hline 23 Feb 1 & 1984 & High & Night & $\operatorname{DS}(6), \mathrm{BP}(1), \mathrm{BI}(10)$ \\
\hline $23 \mathrm{Feb} 1$ & 1984 & Low & Day & $\operatorname{DS}(6), \operatorname{BP}(1), \mathrm{BI}(10)$ \\
\hline 23 Feb 1 & 1984 & High & Day & $\operatorname{DS}(6), \mathrm{BP}(1), \mathrm{BI}(10)$ \\
\hline 23 Feb 1 & 1984 & Low & Night & $\mathrm{DS}(6), \mathrm{BP}(1), \mathrm{BI}(10)$ \\
\hline 23 Mar 1 & 1984 & High & Night & $\mathrm{DS}(6), \mathrm{BP}(1), \mathrm{BI}(10), \mathrm{ET}(2)$ \\
\hline 23 Mar 1 & 1984 & Low & Day & $\mathrm{DS}(6), \mathrm{BP}(1), \mathrm{BI}(10)$ \\
\hline $23 \mathrm{Mar} 1$ & 1984 & High & Day & $\mathrm{DS}(6), \mathrm{BP}(1), \mathrm{BI}(10), \mathrm{ET}(2)$ \\
\hline 23 Маг 1 & 1984 & Low & Night & $\mathrm{DS}(6), \mathrm{BP}(1), \mathrm{BI}(10)$ \\
\hline 24 May 1 & 1984 & Low & Day & $\mathrm{BP}(1)$ \\
\hline 14 Jun 1 & 1984 & Low & Day & $\mathrm{DS}(6), \mathrm{BP}(2), \mathrm{BI}(10)$ \\
\hline $14 \mathrm{Jun} 1$ & 1984 & High & Day & ET $(5)$ \\
\hline $5 \mathrm{Jul}$ & 1984 & High & Night & $\mathrm{DS}(5), \mathrm{BI}(8)$ \\
\hline $5 \mathrm{Jul}$ & 1984 & Low & Day & $\mathrm{DS}(5), \mathrm{BI}(10)$ \\
\hline 5 Jul & 1984 & High & Day & $\operatorname{DS}(5), \mathrm{BI}(10)$ \\
\hline $5 \mathrm{Jul} \quad 1$ & 1984 & Low & Night & DS (5), BI (10) \\
\hline
\end{tabular}

ripples with a brass corer of $23 \mathrm{~mm}$ internal diameter (area $=4.15 \mathrm{~cm}^{2}$ ). As shown previously (Hicks 1984), ripple troughs contain higher copepod densities than crests or surrounding sediment of more uniform microtopography. Sediment samples at Stns 2 to 4 were taken with the same corer; surface ripples did not occur at these sites. Care was taken not to include any part of fresh Zostera blades, especially at Stn 4. All cores were sampled to the depth of the relevant RPD (ca $6 \mathrm{~cm}$ at Stn 1; ca $2 \mathrm{~cm}$ at Stns 2 to 4). Extruded cores were placed in plastic storage jars containing $70 \%$ alcohol and Rose Bengal stain. Collection of copepods was on a $63 \mu \mathrm{m}$ sieve after multiple swirl-decantations.

Two methods were chosen to sample the fauna on seagrass blades. First, large samples were obtained by clipping blades at the base of the blade sheaths within a $10 \times 10 \mathrm{~cm}$ quadrat. This procedure was undertaken with great delicacy to minimize disturbance to resident blade fauna and to ensure the least possible contamination of blades by sediment-dwelling species. Blade samples were subsequently placed into plastic bags containing $70 \%$ alcohol. Second, individual blades were sampled by sliding a plastic tube $(15 \mathrm{~mm}$ internal diameter) over the blade, clipping it as close as possible to the base of the blade sheath, and sealing the end with a shallow bung. The opposite end was unsealed but covered with $63 \mu \mathrm{m}$ mesh. This prevented a bow wave effect when the tube was emplaced, yet denied escape of animals.

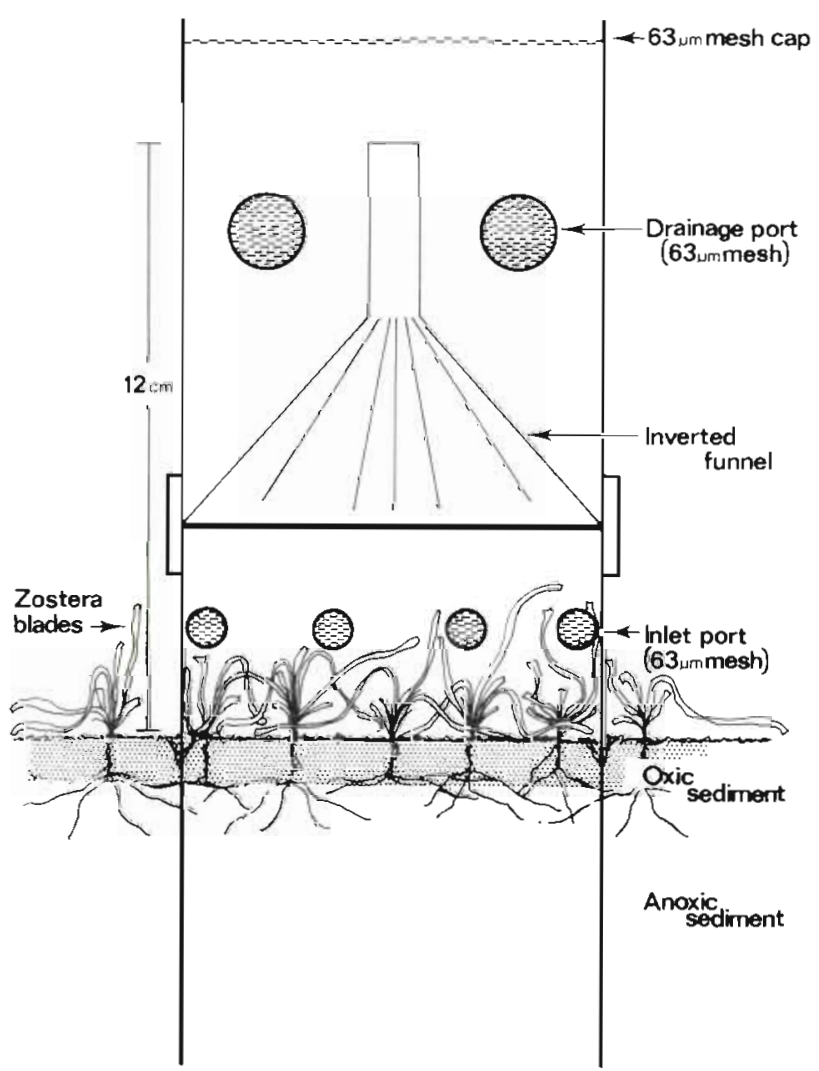

Fig. 1. Schematic illustration of emergence trap. See text for details of emplacement 
Sediment densities and $10 \times 10 \mathrm{~cm}$ quadrat blade densities are expressed as numbers of individuals per $10 \mathrm{~cm}^{2}$ bottom area. Since it is believed that harpacticoids respond directly to surface area of phytal structures (Hicks 1985a), rather than to plant biomass per se, the number of individuals and number of species have been compared with the surface area $\left(\log _{e} \mathrm{~mm}^{2}\right)$ of individual blades. Blade surface areas were determined arithmetically by length: width measurements using dial calipers to the nearest $0.01 \mathrm{~mm}$, accounting for both surfaces.

At high tide on 2 sampling occasions in March 1984 (Table 2), the water column overlying dense Zostera (Stn 4) was sampled with emergence traps; in June 1984, 5 samples of water overlying dense Zostera and 5 taken similarly from bare sand at Stri 1 were compared. Emergence traps consisted of a $10.4 \mathrm{~cm}$ diameter PVC pipe in 2 sections (Fig. 1). The lower section of $15.5 \mathrm{~cm}$ length contained at its top an inverted clear piastic funnel, $2 \mathrm{~cm}$ below which were eight $63 \mu \mathrm{m}$ meshcovered inlet ports to allow water exchange but prevent high flow during a rising tide. The top section fitting tightly into the lower was $15 \mathrm{~cm}$ in length and capped with $63 \mu \mathrm{m}$ mesh. At a level $3 \mathrm{~cm}$ below the top of the funnel additional $63 \mu \mathrm{m}$ mesh-covered ports allowed drainage as the tide ebbed. The whole structure was forced gently into the substratum enclosing Zostera blades (see Fig. 1), allowing approximately $6 \mathrm{~cm}$ remaining above the sediment surface. Copepods entering the device had, of necessity, to actively move a distance of some $12 \mathrm{~cm}$ from the substratum to the top of the inverted funnel in order to be trapped. Emergence traps were emplaced prior to flood tide and retrieved $6 \mathrm{~h}$ later at low tide, thus sampling a complete high water phase.

\section{RESULTS}

\section{Comparison between vegetated and unvegetated substrata}

Since regular samples from each subhabitat over all seasons of the year were not undertaken, temporal aspects of abundance and species richness will not be treated. That such variability does occur, however, is evident in the raw data and in Fig. 2 where summer and winter values have been plotted independently. Both abundancc and species richness on blades and on sediments beneath dense Zostera are significantly higher in June (early winter) than in January (early summer) (ANOVA, $\mathrm{P}<0.001$ in both cases). Summing data from all stations and samples, an inverse parabolic pattern of abundance can be demonstrated with high densities at Stn 1, declining drastically to the margins of Zostera beds and beneath sparse plants, but increasing on sediment beneath dense plants and on the blades themselves (Table 3 ). Taking these latter 2 components together, the abundance of copepods in Zostera beds is only slightly below ( $\mathrm{P}=0.05$ ) that on the rippled sand bank (Stn 1). There are, however, significantly more species on the margins and associated with beds than at Stn 1 (ANOVA, P < 0.001). About twice as many species occur on blades as opposed to sedimentary substrata either inside or outside beds (Table 3 ). Taken as a whole, dense grassbeds
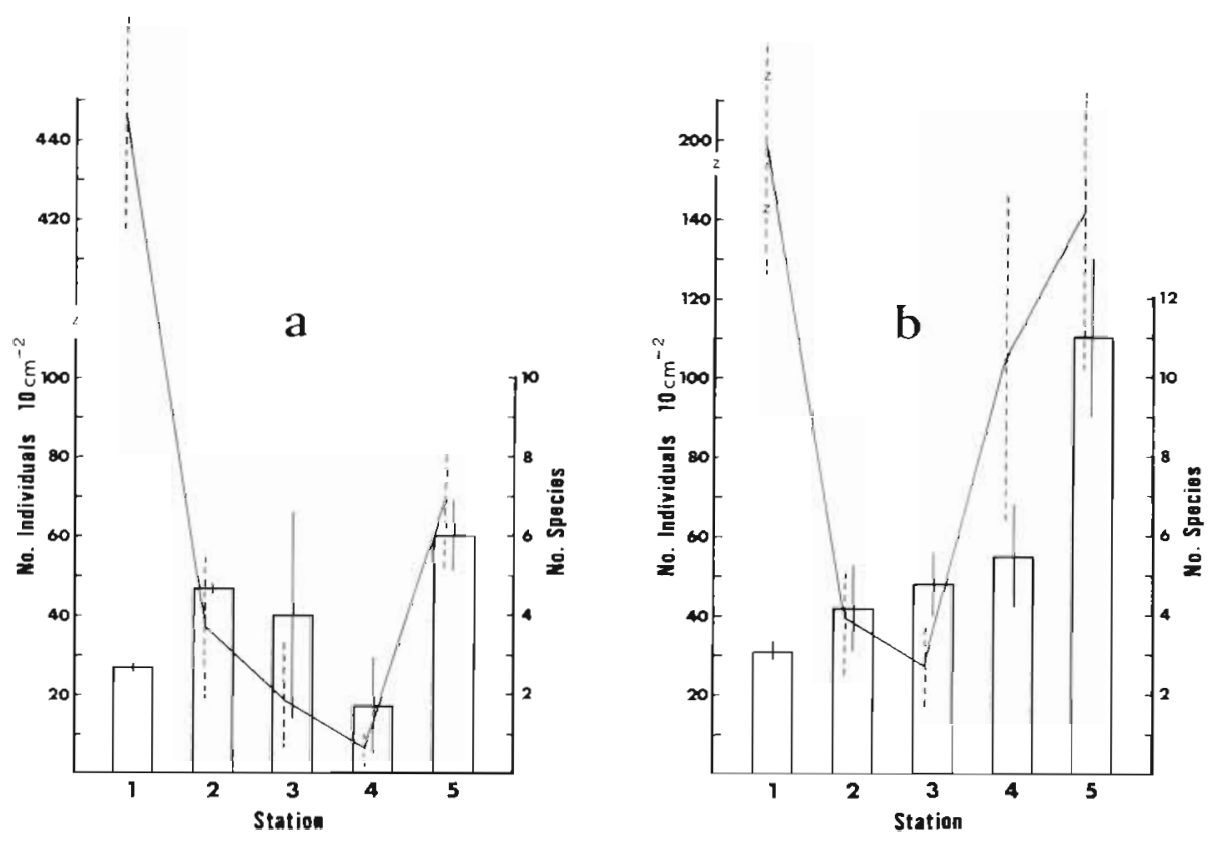

Fig. 2. Mean number ( $\pm 1 \mathrm{SD})$ of individuals (solid line) and mean number $( \pm 1 \mathrm{SD}$ ) of species (bar histograms) of meiobenthic copepods from 5 stations in Pauatahanui Inlet. Stn $1=$ open sand dominated by surface ripples; $\operatorname{Stn} 2=$ open, featureless sand; $\operatorname{Stn} 3$ = sediment amongst sparse Zostera plants; $\operatorname{Stn} 4=$ sediment amongst dense Zostera plants; Stn 5 = Zostera, blades. Samples were taken at low tide during the day (a) in summer, 20 January 1984, and (b) in winter, 14 June 1984 
Table 3. Mean values for numbers of individuals (no. $10 \mathrm{~cm}^{-2}$ ) and species compared over 5 estuarine substrata (see 'Materials \& Methods') at low tide during daylight, Pauatahanui Inlet (underlined values: no significant difference in means; ANOVA and SNK test, $P>0.05$ )

\begin{tabular}{|lrrrrr|}
\hline & Stn 1 & $\operatorname{Stn} 2$ & $\operatorname{Stn} 3$ & $\operatorname{Stn} 4$ & $\operatorname{Stn} 5$ \\
\hline Individuals $10 \mathrm{~cm}^{-2}$ & 230.5 & $\underline{46.5}$ & $\underline{37.8}$ & $\underline{85.5}$ & 68.3 \\
Number of species & 3.0 & $\underline{4.8}$ & $\underline{4.4}$ & $\underline{4.7}$ & 8.9 \\
\hline
\end{tabular}

(i.e. blades and subcanopy sediments), support significantly higher numbers of copepod species, with a number of individuals within the range of values recorded from unvegetated sediment habitats (i.e. Stn 1).

Patterns of copepod abundance within larger $100 \mathrm{~cm}^{2}$ plots of clipped Zostera are well predicted by abundances on individual blades. There is a close correlation between these variables in each sample $(r=0.833, \mathrm{P}<0.001)$; thus abundance of copepods on vegetation has been assessed as a function of surface area of individual blades. Using each blade from all collection dates ( $n=125$, see Table 2$)$, there was a highly significant relation between log surface area, and the logarithms of abundance $(r=0.353$, $\mathrm{P}<0.001)$, and number of species $(r=0.364$, $\mathrm{P}<0.001$ ). However, because of the high $n$ value and clear residual variability, this relation is considered somewhat spurious. If each sampling date is analysed independently, then only in July is a significant correlation obtained between surface area and numbers of species $(r=0.772, \mathrm{P}<0.001)$ and individuals $(r=$ $0.483,0.02>\mathrm{P}<0.05, n=17$ in both cases). Degrees of freedom on other sampling dates varied between 6 and 18 and the strength of the relation varied similarly, but always non-significantly. Thus in general, copepods are responding to some characteristic of seagrass beds unable to be determined at the level of surface area of individual blades.

\section{Comparison with tidal and diel state}

Multiple pairwise comparisons of numbers of individuals and species sampled over $24 \mathrm{~h}$ at different stages of the tide (high tide; low tide) and day (night; day), reveal a pattern of dynamic tidally-coupled changes (Table 4). Significantly more individuals and species of copepods are collected from Zostera blades at low tide than at high tide (Mann Whitney U-test, $\mathrm{P}<0.001$ ), irrespective of light regime (day vs night). In direct contrast, copepods occupying the subcanopy sediments in dense beds show no such significant tidal variability in abundance; there is also no difference in relation to diel state. There is a greater number of species on blades than on sediments irrespective of both tidal or diel state. Data collected over $24 \mathrm{~h}$ periods in January, February, March and July covering 2 semidiurnal tidal events (Tables $2 \& 4$ ), are consistent in showing significant reductions in total (i.e. blade plus subcanopy sediment) copepod abundance during high water, contributed to primarily by the phytal component. Significant reductions in the blade fauna at high tide irrespective of time of day is strongly suggestive of a migratory behaviour coupled to tidal inundation.

In an attempt to 'locate' animals that seemingly depart Zostera beds at high water, a series of incidental samples were taken from a range of adjoining alternative substrata. Random high tide samples included sediments adjacent to beds, attached and drift algae such as Gracilaria and Ulva, and cockleshell rubble from nearby shellfish beds. At none of these additional sites could the 'overflow', determined primarily by species composition and relative abundance, be accounted for. It was therefore decided to sample the water column immediately overlying seagrass beds (see 'Materials and Methods').

Table 4. Mean numbers of individuals and species (in parentheses) from $24 \mathrm{~h}$ samples of Zostera blades and subcanopy sediments, January to July, 1984. Samples circumscribe a low and a high tide each during daylight and at night. $\mathrm{LT}=$ low tide $; \mathrm{HT}=$ high tide. Values are expressed as numbers per individual Zostera blade (A) and number $10 \mathrm{~cm}^{-2}$ of sediment (B). Absolute values are therefore not comparable

\begin{tabular}{|lcccc|}
\hline & $\begin{array}{c}\text { Low tide } \\
\text { Day }\end{array}$ & $\begin{array}{c}\text { High tide } \\
\text { Day }\end{array}$ & $\begin{array}{c}\text { Low tide } \\
\text { Night }\end{array}$ & $\begin{array}{c}\text { High tide } \\
\text { Night }\end{array}$ \\
\hline (A) Zostera blades & & & \\
Jan & $7.2(1.1)$ & $0.2(1.0)$ & $9.5(2.0)$ & $0.8(1.2)$ \\
Feb & $9.7(1.3)$ & $1.0(1.2)$ & $8.4(2.1)$ & $1.4(1.4)$ \\
Mar & $15.7(3.0)$ & $3.5(1.4)$ & $13.4(2.8)$ & $0.9(1.6)$ \\
Jul & $7.8(2.0)$ & $0.5(1.0)$ & $4.3(1.6)$ & $3.1(1.5)$
\end{tabular}

Individuals $\mathrm{LT}$ vs $\mathrm{HT}=\mathrm{P}<0.001$, Mann Whitney U-test Individuals Day $v$ s Night $=$ NS

Species LT vs HT $=\mathrm{P}<0.001$, Mann Whitney U-test Species Day vs Night $=$ NS

(B) Subcanopy sediments

$\begin{array}{lrrrr}\text { Jan } & 57.1(4.3) & 43.4(4.2) & 105.3(4.2) & 88.4(3.8) \\ \text { Feb } & 122.5(5.5) & 127.8(4.8) & 165.9(5.3) & 62.6(4.2) \\ \text { Mar } & 114.1(4.8) & 77.9(4.7) & 98.0(4.3) & 68.7(4.7) \\ \text { Jul } & 106.6(6.4) & 115.2(5.6) & 103.6(5.4) & 97.4(5.0)\end{array}$

Individuals LT $v$ s HT $=N S$

Individuals Day vs Night $=$ NS

Species LT vs HT = NS

Species Day vs Night $=$ NS 


\section{Abundance in emergence traps}

The sequence of high-low tide and low-high tide abundances during both day and night was investigated by analysis of emergence trap data. In March 1984, substantial numbers of copepods were collected in a preliminary duplicate set of traps sampling the water column at both high tide night ( $\bar{x}$ individuals $=$ $72.5 \pm 71.4)$, and high tide day $(\bar{x}=81.0 \pm 49.5)$. To assess the contribution to trap fauna of the underlying substrata, the mean number of copepods from sediments together with those on blades were pooled and expressed as number of individuals per $100 \mathrm{~cm}^{2}$. The internal area of the emergence trap is equivalent to $104 \mathrm{~cm}^{2}$. By direct proportionality of abundance on the substratum during the preceding low tide, the number of copepods collected in traps over the following high water phase accounted for $3.8 \%$ of the 'available' fauna on sediments and blades at high water night and $3.6 \%$ at high water day. The similarity in these 2 values confirms the absence of significant day-night variability in the faunas resident on blades and sediments (see above). The trap collections also verify the movement of copepods into the immediately overlying water column as suggested by sampling blades and sediment alone. Refinements have been made to this preliminary sampling strategy and many more samples have since been taken which confirm this fundamental pattern. Details of these aspects will form the basis of a forthcoming account (Bell, Hicks \& Walters unpubl.).

To test that these tidal migrations are indeed active phenomena of copepods associated with seagrass habitats rather than the result of passive resuspension as found over unvegetated sediments (sensu Palmer 1984, Palmer \& Gust 1985), 5 traps were set in June 1984 on open unvegetated sand (Stn 1), and 5 over dense Zostera beds (Stn 4). Results are presented in Table 5, establishing a highly significant difference (ANOVA, $\mathrm{P}<0.001$ ) between the 2 subhabitats. Over an order of magnitude more copepods were retrieved from traps emplaced over a vegetated bottom, compared with those from an unvegetated site.

\section{Species composition}

Thirty copepod species have been collected from the 364 samples covering all substrata (see Materials and Methods'; Table 2). Most of these are in need of critical taxonomic verification. Numerically, Porcellidium sp. and Bulbamphiascus sp. were the most abundant species on seagrass blades and subcanopy sediments, respectively (Table 6). On sediments amongst sparse plants and on closely adjacent unvegetated sites there was no clear dominant; instead the bulk of the fauna was contributed to by Paralaophonte sp., Bulbamphiascus sp., Parastenhelia megarostrum, and to a lesser extent Halectinosoma hydrofuge. All sedimentdwellers so categorized are either epibenthic or shallow burrowers, but an interstitial species, Paraleptastacus sp., attained high localized densities at Stn 1 during this sampling period. Some species, e.g. Ectinosoma melaniceps and $H$. hydrofuge, have been categorized as phytal itinerants since their abundance is roughly shared between blades and subcanopy sediments; in the case of the former, there was no statistical difference between abundance on both substrata. Other species exhibit distinct distribution patterns in relation to the presence of seagrass. Stn 1 is clearly optimal for Paraleptastacus sp,; clean fine sand becoming progressively more silt laden towards seagrass beds, presumably occluding necessary pore space required by this strictly interstitial species. Parastenhelia megarostrum, Robertsonia propinqua and Paralaophonte aenigmaticum, also found predominantly on the clean fine sand bank at Stn 1 (see Hicks 1984), decline in absolute abundance towards the edges of seagrass beds. Conversely, abundance of Bulbamphiascus sp. increases proportionally from open unvegetated sediment (Stn 2) to that beneath dense Zostera plants. Relative abundance of Tisbe furcata is predictably highest on blades, as it is for other typically phytal species including Paradactylopodia brevicornis, Harpacticus sp., Amphiascus pacificus, Laophonte inornata and Amphiascopsis cinctus. Together with Porcellidium sp., these species are prob-

Table 5. Comparison of migrating copepods between vegetated and unvegetated sites. $\mathrm{HW}=$ high water Abundances on substratum are values taken at preceding low water

\begin{tabular}{|c|c|c|c|c|c|}
\hline Site & $\begin{array}{l}\text { Date } \\
(1984)\end{array}$ & No. samples & $\begin{array}{l}\text { Abundance on } \\
\text { substratum } 100 \mathrm{~cm}^{-2}\end{array}$ & $\begin{array}{l}\text { Mean no. caught } \\
\text { per } 6 \text { h }(\mathrm{HW})\end{array}$ & $\begin{array}{l}\% \text { of 'available' } \\
\text { fauna }\end{array}$ \\
\hline $\begin{array}{l}\text { Bare sand } \\
\text { (Stn 1) }\end{array}$ & 14. Jun & 5 & $2000 \pm 400^{\star}$ & $19.5 \pm 6.9$ & 0.975 \\
\hline $\begin{array}{l}\text { Over Zostera bed } \\
\text { (Stns } 4,5)\end{array}$ & 14 Jun & 5 & $1899^{b}$ & $244.8 \pm 159.3$ & 13.1 \\
\hline \multicolumn{6}{|c|}{$\begin{array}{l}\text { Mean of } 5 \text { cores } \\
\text { Sum of subcanopy sediment ( } \bar{x} \text { of } 6 \text { cores) plus blade (total of one } 10 \times 10 \mathrm{~cm} \text { clipped plot) values }\end{array}$} \\
\hline
\end{tabular}


Table 6. Total and relative abundance of copepod fauna collected from 5 microhabitats (Stn $1=$ open, sand ripples; Stn $2=$ open, featureless sand; Stn 3 = sediment amongst sparse Zostera plants; $\operatorname{Stn} 4=$ sediment amongst dense Zostera plants; Stn $5=$

Zostera blades). Arbitrary categories ranked as primarily blade-dwellers (B); sediment-dwellers (S); itinerants (I), see text

\begin{tabular}{|c|c|c|c|c|c|c|c|c|c|c|c|}
\hline \multirow[t]{2}{*}{ Species } & \multicolumn{2}{|c|}{ Stn 1} & \multicolumn{2}{|c|}{$\operatorname{Stn} 2$} & \multicolumn{2}{|l|}{ Stn 3} & \multicolumn{2}{|c|}{$\operatorname{Stn} 4$} & \multicolumn{2}{|c|}{ Stn 5} & \multirow[t]{2}{*}{ Category } \\
\hline & Number & $\%$ & Number & $\%$ & Number & $\%$ & Number & $\%$ & Number & $\%$ & \\
\hline Porcellidium sp. & & & & & & & 3 & 0.08 & 7719 & 85.3 & $\mathrm{~B}$ \\
\hline Bulbamphiascus sp. & & & 55 & 17.7 & 48 & 27.3 & 2185 & 55.1 & 76 & 0.84 & $\mathrm{~S}$ \\
\hline Halectinosoma hydrofuge & & & 46 & 14.8 & 22 & 12.5 & 812 & 20.5 & 205 & 2.3 & I \\
\hline Paraleptastacus sp. & 794 & 56.1 & 8 & 2.6 & & & & & & & $\mathrm{~S}$ \\
\hline Paralaophonte sp. & 1 & 0.09 & 54 & 17.4 & 41 & 23.3 & 405 & 10.2 & 13 & 0.14 & $\mathrm{~S}$ \\
\hline Tisbe furcata & & & & & 1 & 0.57 & 34 & 0.86 & 397 & 4.4 & B \\
\hline Ectinosoma melaniceps & & & 2 & 0.64 & 3 & 1.7 & 239 & 6.0 & 352 & 3.9 & I \\
\hline Parastenhelia megarostrum & 578 & 40.8 & 97 & 31.2 & 18 & 10.2 & 6 & 0.15 & & & $\mathrm{~S}$ \\
\hline Halicylops sp. & & & 19 & 6.1 & 6 & 3.4 & 176 & 4.4 & 25 & 0.28 & $\mathrm{~S}$ \\
\hline Paradactylopodia brevicornis & & & 1 & 0.32 & 3 & 1.7 & 7 & 0.18 & 118 & 1.3 & B \\
\hline Enhydrosoma sp. & & & 7 & 2.3 & 15 & 8.5 & 76 & 1.9 & & & S \\
\hline Robertsonia propinqua & 40 & 3.5 & 15 & 4.8 & 15 & 8.5 & 1 & 0.03 & & & S \\
\hline Harpacticus sp. & & & & & & & 1 & 0.03 & 70 & 0.77 & B \\
\hline Amphiascus pacificus & & & & & & & 3 & 0.08 & 40 & 0.44 & B \\
\hline Paralaophonte aenigmaticum & 3 & 0.26 & 4 & 1.3 & 1 & 0.57 & 3 & 0.08 & & & $\mathrm{~S}$ \\
\hline Laophonte inornata & & & & & & & 4 & 0.10 & 8 & 0.09 & I \\
\hline Amphiascopsis cinctus & & & & & & & & & 8 & 0.09 & B \\
\hline Psyllocamptus minutus & & & & & & & 2 & 0.05 & 6 & 0.07 & I \\
\hline Quinquelaophonte candelabrum & & & 1 & 0.32 & 3 & 1.7 & 1 & 0.03 & & & $\mathrm{~S}$ \\
\hline Pseudostenhelia sp. & 1 & 0.09 & 2 & 0.64 & & & & & & & $\mathrm{~S}$ \\
\hline Mesochra sp. & & & & & & & 2 & 0.05 & 1 & 0.01 & $\mathrm{I}$ \\
\hline Metis sp. & & & & & & & & & 2 & 0.02 & $\mathrm{~B}$ \\
\hline Ameiridae & & & & & & & & & 2 & 0.02 & $\mathrm{~B}$ \\
\hline Enhydrosomella sp. & & & & & & & 1 & 0.03 & 1 & 0.01 & I \\
\hline Stylicletodes sp. & & & & & & & 2 & 0.05 & & & $\mathrm{~S}$ \\
\hline Amphiascus ?gracilis & & & & & & & & & 1 & 0.01 & $\mathrm{~B}$ \\
\hline Harpacticus sp. A. & & & & & & & & & 1 & 0.01 & $\mathrm{~B}$ \\
\hline Brianola sp. & & & & & & & & & 1 & 0.01 & $\mathrm{I}$ \\
\hline Typhlamphiascus sp. & & & & & & & 1 & 0.03 & & & $\mathrm{~S}$ \\
\hline Halectinosoma otakoua & & & & & & & 1 & 0.03 & & & $\mathrm{~S}$ \\
\hline Total no. copepods & 1416 & & 311 & & 176 & & 3965 & & 9046 & & \\
\hline Total no. species & 6 & & 13 & & 12 & & 22 & & 20 & & \\
\hline
\end{tabular}

ably so localized because of feeding preferenda from vegetative rather than clastic surfaces.

No one species showed any positive association with surface area of individual seagrass blades.

Similar pairwise comparisons to those made on total numbers of species and individuals (see above) have been carried out on the 6 most abundant species from blades and subcanopy sediments. As expected, results for total fauna are reflected in individual species with both blade and itinerant forms showing significant differences in abundance at low compared to high tide (Table 7 ). The reduction in abundance at high tide demonstrated for Porcellidium sp., Tisbe furcata, Ectinosoma melaniceps and Halectinosoma hydrofuge, is not supported in those species categorized as primarily sediment-dwellers. Although exhibiting similar tidal variability, results for Bulbamphiascus sp. are not quite significant at the $95 \%$ confidence level.
Of all species associated with seagrass beds, only $T$. furcata shows any indication of a greater loss of individuals at high tide during the day, compared to the same tidal state at night. These data, however, suffer the same fate as those for Bulbamphiascus sp. (see Table 7). Examination of relative abundances of the commonest species suggests that only a proportion of the population of each species is moving off plants or subcanopy sediments at high tide, rather than the entire population of 1 or 2 species alone. This is supported by the emergence trap catches which are sampling all of the common species occupying both blade and subcanopy sediments (Table 8). Note that of the species undergoing active migration from the substratum into the water column, over $70 \%$ of the fauna (discounting unidentifiable nauplii), is derived directly from blades or as phytal itinerants. Bulbamphiascus sp. is the only sediment-dweller to contribute 
Table 7. Mann-Whitney probabilities of significant differences in both diel and tidal abundances of the 6 most abundant species associated with seagrass beds

\begin{tabular}{|lcc|}
\hline Species & Low tide/Hightide & Day/Night \\
\hline $\begin{array}{l}\text { Blade dwellers } \\
\text { Porcellidium sp. }\end{array}$ & $\mathrm{P}<0.001$ & $\mathrm{NS}$ \\
$\begin{array}{l}\text { Tisbe furcata } \\
\text { Itinerants }\end{array}$ & $\mathrm{P}<0.001$ & $0.05>\mathrm{P}<0.10$ \\
$\begin{array}{l}\text { Ectinosoma melaniceps } \\
\text { Halectinosoma hydrofuge }\end{array}$ & $\mathrm{P}<0.05$ & $\mathrm{NS}$ \\
$\begin{array}{l}\text { Sediment-dwellers } \\
\text { Bulbamphiascus sp. }\end{array}$ & $0.05>\mathrm{P}<0.10$ & $\mathrm{NS}$ \\
Paralaophonte sp. & $\mathrm{NS}$ & $\mathrm{NS}$ \\
\hline
\end{tabular}

at all substantially to trap results. Full species analysis of emergence trap data will be presented at a later date (Bell, Hicks \& Walters unpubl.).

\section{DISCUSSION}

In this examination of estuarine copepods, dense beds of Zostera capricorni supported an average of twice as many sediment-dwelling individuals as the sparsely vegetated fringes of beds and immediately adjoining unvegetated sediments. Together, dense bed blade and subcanopy sediment densities can approximate abundances in a nearby unvegetated sand ripple system (Stn 1), which has been shown to maintain very high peak harpacticoid densities (Hicks 1984). Furthermore, Zostera blades alone are capable of supporting more than double the number of species than other sites elsewhere on Mana Bank. It is now axiomatic that areas of increased floristic density, architecture or biomass contain more species and greater abundance of epibenthic and phytal invertebrates than do areas of reduced floristic equivalents (see Heck \& Orth 1980, Hicks 1985a for reviews). The practical operation of such a relation exists in the provision, via higher levels of complexity or heterogeneity, of an increased habitable space (= number of microhabitats), and the formation of protected living centers (refuges) from predators and/or hydrodynamic disturbance. Initial analyses here, using surface area of individual blades, a technique employed successfully in other studies on phytal meiofauna (Hicks 1980, Coull \& Wells 1983), show little in the way of a direct relation linking copepod abundance and species richness to blade surface area. In certain circumstances (e.g. highly turbid waters) it is known that the sensitivity of surface area measures is impaired (Hicks 1980), and in this instance surface area of individuai blades would seem to be an inappropriate technique. Seagrass biomass has commonly been used for correlative assessments of macrofaunal abundance and diversity (Heck \& Wetstone 1977, Stoner 1980, Lewis 1984), and a gross measure such as this, although biologically less meaningful than surface area (at least to surficially sensitive copepods!), may prove to be a more useful measure of habitat 'abundance' against which to evaluate the number and diversity of meiofaunal copepods. The only time at which a significant abundance and species richness relation with blade surface area was found was during winter (July) when Zostera biomass is reduced on Mana Bank, yet copepod abundance and number of species is high. It may be that at this time, reduced availability of the phytal substratum impacted upon

Table 8. Mean and relative abundances of the copepod fauna collected in emergence traps ( $\mathrm{n}=5$ ), emplaced over dense Zostera bed, Pauatahanui Inlet, 14 June 1984. Categories are those in Table 6. Values integrate an entire $6 \mathrm{~h}$ high tidal phase

\begin{tabular}{|c|c|c|c|c|c|}
\hline Species & & $\begin{array}{l}\text { Mean number per } \\
104 \mathrm{~cm}^{2} \text { trap }\end{array}$ & $\mathrm{SD}$ & $\%$ & Category \\
\hline Halectinosoma hydrofuge & & 60.4 & 38.0 & 24.6 & I \\
\hline Tisbe furcata & & 57.0 & 27.7 & 23.2 & $\mathrm{~B}$ \\
\hline Bulbamphiascus sp. & & 46.5 & 25.6 & 15.2 & $\mathrm{~S}$ \\
\hline Ectinosoma melaniceps & & 32.4 & 26.1 & 13.2 & I \\
\hline Porcellidium sp. & & 25.6 & 28.2 & 10.4 & B \\
\hline Unidentified nauplii & & 16.4 & 21.9 & 6.7 & - \\
\hline Paralaophonte sp. & & 14.3 & 15.1 & 4.6 & S \\
\hline Halicylops sp. & & 3.7 & 1.5 & 0.90 & $\mathrm{~S}$ \\
\hline Paradactylopodia brevicornis & & 2.3 & 1.5 & 0.73 & B \\
\hline Amphiascus pacificus & & 2 & - & 0.16 & B \\
\hline Halectinosoma otakoua & & 1 & - & 0.08 & S \\
\hline Quinquelaophonte candelabrum & & 1 & - & 0.08 & $S$ \\
\hline Total no. species & 11 & & & & \\
\hline Total no. individuals & 1226 & & & & \\
\hline
\end{tabular}


the copepod species to force some degree of habitat fractionation on blades. In this way the influence of habitat 'scale' might better predict significant associations between density, species and surface area (see Edgar 1983, Hicks 1985a). Alternatively the more turbulent conditions during winter might resuspend fine particles that had settled on blades over the earlier and more tranquil part of the year. Accumulation of silts on blades would alter the fundamental habitable surface, appreciably reduce the realized surface, and modify the predicted relation between species richness, abundance and surface area (Hicks 1980). Non-significant or even inverse correlations between abundance, diversity and individual blade surface area in summer, when total Zostera biomass is higher, implies that either copepod populations are not intimately linked to the 'abundance' (biomass) of Zostera (see Nelson 1979), or that such predicted links are out of phase (Stoner 1983), perhaps because of siltation of blades. More experimental work is needed to accurately define which measure of plant abundance might significantly affect density and diversity of the copepod subcommunity. Because of the rather uniform morphology of Zostera blades and above ground structures, and the largely unknown behavioural responses of most copepods to vegetative structure, it is conceivable that such relations might not operate in seagrass meiofaunal communities to the extent demonstrated in marine algal systems.

With the revelation here that meiobenthic copepod abundance and species richness are significantly greater inside seagrass beds (blades plus subcanopy sediments) than on closely adjoining unvegetated sand flats, a condition has arisen which reiterates that frequently reported for the macrobenthos (e.g. Kikuchi 1967, Reise 1977, Stoner 1980, 1983, Lewis 1984, Summerson \& Peterson 1984 - but see Decho et al. 1985). Hypotheses advanced to explain this pattern include a larval and food accumulation mechanism whereby above-ground seagrass structures (blades, sheaths etc.), act as 'filters' to suspended food and larvae thus concentrating them amongst blades and subcanopy sediments (e.g. Peterson et al. 1984). An alternative view argues inhibition of predatory efficiency with seagrass structures serving to disrupt actively hunting predators such as fish, crab and shrimp. Physical structures of plants provide refuge for prey which are more effectively controlled by predation in habitats without such interrupting structures (see Heck \& Orth 1980). Summerson \& Peterson (1984) have examined more specifically the distribution of predators inside and outside seagrass beds and propose a modification of this latter hypothesis. It predicts that epibenthic predators themselves use seagrass beds as refuges from higher order predators during daylight, and for safety reasons, restrict themselves to nocturnal foraging over open unvegetated habitats. The intensity of predation is therefore suspected to be lower the further away from a seagrass refuge used by a predator. While critical field experimental work remains to be done on these aspects as related to meiofaunal populations, results herein have some bearing on this hypothesis.

Sediment-dwelling copepod abundances decline from within dense seagrass beds (Stn 4) to open unvegetated sediment (Stn 2), but increase significantly even further away from beds (Stn 1). At first sight this distribution pattern would tend to support Summerson \& Peterson's predictions, with areas immediately adjacent to dense beds (Stns 2 \& 3) suffering greatest assumed predatory exploitation (average abundance being half that in dense beds). When account is taken of the natural history of the component species, however, a differing view emerges. First, the species contributing most to total abundance at Stn 1 during this survey was the interstitial form Paraleptastacus sp. This species lives deep in the sediment down to the level of the RPD (0 to $6 \mathrm{~cm}$ ), and does not suffer loss to surface-feeding macrobenthic predators whether or not they reside diurnally in beds. Second, Parastenhelia megarostrum is known to be heavily cropped by flatfish predators at Stn 1 (Hicks 1984), and third, those fish species of appropriate size caught from within grass beds have always had guts containing predominantly phytal harpacticoids (pers, obs.). Sediment-dwellers inside dense Zostera beds (mainly Bulbamphiascus sp., Paralaophonte sp. and Halicyclops sp.), may thus escape significant predation because of the protective canopy formed by blades (sensu Heck \& Orth 1980), which may explain the higher mean densities at Stn 4 than in areas with sparser overhead cover (Stns $2 \& 3$ ). These features combine to cast doubt on the efficacy of Summerson \& Peterson's notion, at least for meiofauna, that predation should decline as a function of increasing distance from seagrass bed refuges utilized by epibenthic predators. Instead it would seem that copepods living on open unvegetated sediments are preyed upon by a suite of either cryptic (e.g. flatfish) or burrowing (e.g. mud crabs) macropredators whilst seagrass-dwelling species fall prey to a completely different suite of vegetation picker-type predators (viz. labrids, syngnathids). The latter are specifically localized amongst the protective cover of seagrass vegetation itself (e.g. Howard \& Koehn 1985, pers. obs.). Such a distinction would appear to be more prevalent among macrofauna-meiofauna interactions than the strictly macrofauna-macrofauna interactions alluded to by Summerson \& Peterson (1984).

Observations of a sequential 'loss' of individuals from grassbed microhabitats during each high tide necessitated a sampling of the water column immedi- 
ately overlying beds. Data accumulated from emergence traps have established conclusively an active swimming of members of the Zostera copepod assemblage, with individuals trapped representing the range of species available. During daytime low water periods, high abundances of copepods are generally found associated with the substratum; subsequent daytime high water periods exhibit abundances on subcanopy sediments and blades that are each reduced when compared to previous low tide values. This same sequence of high-low tide and low-high tide abundances is repeated during night-time tides suggesting a lack of any light-induced emergence cue. The implication from these data is that a substantial component of the fauna was leaving the seagrass bed during the flood tide and returning to it on the ebb. Using similar techniques in an essentially atidal, tropical (Tampa Bay, Florida) seagrass bed dominated by the turtlegrass Thalassia testudinum, Bell et al. (1984) have revealed an equivalent emergence phenomenon amongst harpacticoids and to a lesser extent, other components of the meiobenthos. Unlike the tidallycoupled emergence behaviour found in Pauatahanui Inlet, the Tampa Bay data show a pronounced pulse of copepods migrating into the water column at sunset. In the absence of what for the Pauatahanui populations may ultimately prove to be pressure-related cues linked to tidal inundation (Morgan 1984), populations in Florida would seem alternatively to be stimulated by differences in ambient light regime (Walters unpubl.).

Over $86 \%$ of the individuals found to be actively swimming and consequently collected in emergence traps belonged to 5 species. Of these, only Bulbamphiascus sp. can be categorized as primarily sedimentary in its habitat choice. The remaining $71 \%$ of individuals are comprised of typically phytal or itinerant species (Ectinosoma melaniceps herein categorized as itinerant is frequently considered a phytal species Dahl 1948, Hagerman 1966, Hicks 1980, Coull et al 1983). That most migrating individuals from seagrass habitats are associated in some way with the vegetation coincides with what is already known of harpacticoid copepods from algal biotopes. In these, a number of species have been documented as exhibiting welldeveloped swimming capabilities (see Lang 1948, Hauspie \& Polk 1973, Pallares \& Hall 1974a, b), with, in some cases, the suggestion of pronounced tidal rhythmicity (Wieser 1952). Active swimming in obligatory sediment-dwelling harpacticoids such as epibenthicburrowing members of the Cletodidae, some Tachididae and some Diosaccidae, has yet to be definitively reported. Recent demonstrations of transport into the water column of epibenthic and infaunal species belonging to these families, as a consequence of mechanical resuspension due to bottom shear currents (Palmer 1984, Palmer \& Gust 1985), have forced a reappraisal of the association of these organisms with bottom sediments (see also Bell \& Sherman 1980, Palmer \& Brandt 1981, Fleeger et al. 1984). Palmer \& Gust's (1985) contention, that the occurrence of copepods in the water column is a passive erosional phenomenon rather than active behavioural emergence, unquestionably holds for their open unvegetated mud site, but cannot be sustained for the faunas of vegetated habitats. Emergence trap samples collected concurrently over dense Zostera beds and over unvegetated sediments indicate a significantly different behavioural response from the component faunas of each biotope. Bare sand (Stn 1) is dominated epibenthically by parastenhelia megarostrum which. for a similar ambient substratum abundance, is retrieved over an order of magnitude less than species over a vegetated habitat. The insignificant occurrence of bare sand-dwelling copepods in traps through default, in fact, supports Palmer \& Gust (1985), i.e. active swimming is not a feature of strictly sedimentdwelling species. Taking regard of the situation over vegetated sites, however, a significant swimming component exists. Moreover, from a taxo-ecological perspective, the majority of migrating animals belong to typically phytal genera and/or species, previously acknowledged for their swimming prowess. Clearly there is a pronounced divergence in the behaviour of copepod faunas from vegetated and unvegetated systems. The view that passive resuspension is the primary way in which meiofaunal copepods enter the water column does not take sufficient account of the unique differences between such habitats and their resident biota. Systems containing an important phytal component could be expected therefore to contribute some of its members to the water column at certain times (tidally and/or diurnally-nocturnally variable). The precedent of behavioural emergence rhythms in small crustaceans has after all been set, and has a long history in the biological literature (see Morgan 1984).

Active benthic-pelagic exchanges have profound implications for the ecological dynamics of seagrass habitats. Vertical migration into the water column of substantial numbers of copepods at each high tide is a pathway of biomass transfer between benthic and pelagic realms. This organic material is a potential energy source for midwater feeding predators (Robertson \& Howard 1978, Burchmore et al. 1984). Copepods migrating during daylight high water may become selected food items for visually feeding fishes which move over grassbeds with the rising tide (pers. obs.). Indeed, tidally invading epibenthic predators might 'stimulate' prey to swim as an escape response (Alldredge \& King 1977. Ambrose 1984). If this were so, 
then preferential night-time movements could equally be interpreted as a strategy for predator avoidance. Most fishes associated with seagrass beds are daytime feeders (Bell \& Harmelin-Vivien 1983, Sogard 1984 , Howard \& Koehn 1985), with some foraging in the water column during the day, and resting or sleeping close to the substratum at night (Bell \& HarmelinVivien 1983). One of the most important phytal copepod-feeding fishes residing in Zostera beds in Pauatahanui Inlet (Pseudolabrus celidotus), can be observed sleeping amongst blades at night. Robertson \& Howard (1978), on the contrary, found that fish feeding activity was maintained at night over Zostera beds in Australia, but with a switch in the predominant predator and the type of prey selected. The present investigation has established that migration of seagrass copepods occurs at high tide not only at night, but also during the day. It would seem therefore that the utility of vertical excursions into the water column as a tactic to reduce risk of predation, particularly when linked to a diurnal versus nocturnal perspective, is not universally important with respect to seagrass copepods.

Bottom feeding copepods would also carry nutrients from sediments and blades into the water column. Bacterial and microalgal biomass, the predominant food of meiofaunal copepods (Hicks \& Coull 1983), would be released as excretory products into the water whereas it might otherwise remain bound to bottom deposits. The involvement of seagrass bed faunas as intermediaries in the broader context of nutrient exchange in estuarine systems has yet to be fully assessed. Despite this a parallel exists whereby transfer of nutrients by fish which move nocturnally from open water to rocky reefs (e.g. Bray et al. 1981) can be viewed similarly to migratory activities of seagrass copepods.

There are also important implications for meiofaunal subcommunity structure. Tidally alternating variations in not only absolute but relative abundance, species richness and species composition, indicate that our traditional view of meiofaunal populations being locally static yet varying temporally needs drastic revision. The dynamic nature of these copepod populations over very short time scales (tidal cycles), demonstrate that rigid sampling routines, usually constrained to low tides because of logistical ease, are providing only part of the complex picture. Upon entering the water column, the potential for enhanced dispersal to new habitat patches, particularly for such well-known opportunists as Tisbe (Lopez 1982), together with rapid reorganization of microspatial patterns (Findlay 1981, Hicks 1984), emphasizes the great impact benthicpelagic links of this kind could have on assemblage structure. All of the above implications have yet to be critically examined, but currently underway is a detailed analysis of individual species migratory patterns (Bell, Hicks \& Walters unpubl.), in an attempt to understand the functional rationale behind emergence behaviour of seagrass copepods.

Acknowledgements. I gratefully acknowledge the assistance provided by Susan S. Bell toward the latter stages of the sampling programme and for her enthusiastic discussions and suggestions which have greatly improved the manuscript. The masterful construction of the emergence traps by George $\mathrm{H}$. Grainger is appreciated.

\section{LITERATURE CITED}

Alheit, J., Scheibel, W. (1982). Benthic harpacticoids as a food source for fish. Mar. Biol. 70: 141-147

Alldredge, A. L., King, J. M. (1977). Distribution, abundance and substrate preferences of demersal reef zooplankton at Lizard Island lagoon, Great Barrier Reef. Mar. Biol. 41: $317-333$

Ambrose, W. G., Jr. (1984). Increased emigration of the amphipod Rhepoxynius abronius (Barnard) and the polychaete Nephtys caeca (Fabricius) in the presence of invertebrate predators. J. exp. mar. Biol. Ecol. 80: 67-75

Bell, J. D., Harmelin-Vivien, M. C. (1983). Fish fauna of French Mediterranean Posidonia oceanica seagrass meadows. 2. Feeding habits. Tethys 11: 1-14

Bell, S. S., Sherman, K. M. (1980). A field investigation of meiofaunal dispersal: tidal resuspension and implications. Mar. Ecol. Prog. Ser. 3: 245-249

Bell, S. S., Walters, K., Kern, J. C. (1984). Meiofauna from seagrass habitats: A review and prospectus for future research. Estuaries 7: 331-338

Bray, R. N., Miller, A. C., Geesey, G. G. (1981). The fish connection: A trophic link between planktonic and rocky reef communities. Science 214: 204-205

Burchmore, J. J., Pollard, D. A., Bell, J. D. (1984). Community structure and trophic relationships of the fish fauna of an estuarine Posidonia australis seagrass habitat in Port Hacking, New South Wales. Aquat. Bot. 18: 71-87

Coull, B. C., Creed, E. L., Eskin, R. A., Montagna, P. A., Palmer, M. A., Wells, J. B. J. (1983). Phytal meiofauna from the rocky intertidal at Murrells Inlet, South Carolina. Trans. Am. microsc. Soc. 102: 380-389

Coull, B. C., Wells, J. B. J. (1983). Refuges from fish predation: experiments with phytal meiofauna from the New Zealand rocky intertidal. Ecology 64: 1599-1609

Dahl, E. (1948). On the smaller Arthropoda of marine algae, especially in polyhaline waters off the Swedish West Coast. Undersokningar over Oresund 35: 1-193

Decho, A. W., Hummon, W. D., Fleeger, J. W. (1985). Meiofauna-sediment interactions around subtropical seagrass sediments using factor analysis. J. mar. Res. 43: $237-255$

Edgar, G. J. (1983). The ecology of south-east Tasmanian phytal animal communities. III. Patterns of species diversity. J. exp. mar. Biol. Ecol. 70: 181-203

Findlay, S. E. G. (1981). Small-scale spatial distribution of meiofauna on a mud- and sandflat. Estuar. coast. Shelf Sci. 12: $471-484$

Fleeger, J. W., Chandler, G. T., Fitzhugh, G. R., Phillips, F. E. (1984). Effects of tidal currents on meiofauna densities in vegetated salt marsh sediments. Mar. Ecol. Prog. Ser. 19: 49-53 
Gee, J. M., Warwick, R. M., Davey, J. T., George, C. L. (1985) Field experiments on the role of epibenthic predators in determining prey densities in an estuarine mudflat. Estuar. coast. Shelf Sci. 21: $429-448$

Hagerman, L. (1966). The macro- and microfauna associated with Fucus serratus L., with some ecological remarks. Ophelia 3: 1-43

Hauspie, R., Polk, P. (1973). Swimming behaviour patterns in certain benthic harpacticoids (Copepoda). Crustaceana 25: 95-103

Healy, W. B. (ed.) (1980). Pauatahanui Inlet - an environmental study. N.Z. DSIR Inform. Ser. 141: 1-198

Heck, K. L., Jr. (1979). Some determinants of the composition and abundance of motile macroinvertebrate species in tropical and temperate turtlegrass (Thalassia testudinum) meadows. J. Biogeogr. 6: 183-200

Heck, K. L., Jr., Orth, R. J. (1980). Seagrass habitats: the roles of habitat complexity, competition and predation in structuring associated fish and motile macroinvertebrate assemblages. In: Kennedy, V. S. (ed.) Estuarine perspectives. Academic Press, New York, p. 449-464

Heck, K. L., Jr., Wetstone, G. S. (1977). Habitat complexity and invertebrate species richness and abundance in tropical seagrass meadows. J. Biogeogr. 4: 135-142

Hicks, G. R. F. (1980). Structure of phytal harpacticoid copepod assemblages and the influence of habitat complexity and turbidity. J. exp. mar. Biol. Ecol. 44: 157-192

Hicks, G. R. F. (1984). Spatio-temporal dynamics of a meiobenthic copepod and the impact of predation-disturbance. J. exp. mar. Biol. Ecol. 81: 47-72

Hicks, G. R. F. (1985a). Meiofauna associated with rocky shore algae. In: Moore, P. G., Seed, R. (ed.) The ecology of rocky coasts. Hodder \& Stoughton, London, p. 36-56

Hicks, G. R. F. (1985b). Biomass and production estimates for an estuarine meiobenthic copepod, with an instantaneous assessment of exploitation by flatfish predators. N.Z. Jl Ecol. 8: 125-127

Hicks, G. R. F., Coull, B. C. (1983). The ecology of marine meiobenthic harpacticoid copepods. Oceanogr. mar. Biol. A. Rev. 21: 67-175

Howard, R. K., Koehn, J. D. (1985). Population dynamics and feeding ecology of pipefish (Syngnathidae) associated with eelgrass beds of Western Port, Victoria. Aust. J. mar. Freshwat. Res. 36: 361-370

Kikuchi, T. (1967). An ecological study on animal communities of the Zostera belt in Tomioka Bay, Amakusa, Kyushu. Publs Amakusa mar. biol. Lab. 1: 1-106

Lang, K. (1948). Monographie der Harpacticiden. Hakan Ohlsson, Lund

Lewis, F. G. (1984). Distribution of macrobenthic crustaceans associated with Thalassia, Halodule and bare sand substrata. Mar. Ecol. Prog. Ser. 19: 101-113

Lewis, J. B., Hollingworth, C. E. (1982). Leaf epifauna of the seagrass Thalassia testudinum. Mar. Biol. 71: 41-49

Lopez, G. W. (1982). Short-term population dynamics of Tisbe cucumariae (Copepoda: Harpacticoida). Mar. Biol. 68: 333-341

Mann, K. H. (1972). Macrophyte production and detritus food chains in coastal waters. Memorie Ist. ital. Idrobiol. 29: 353-383

Morgan, E. (1984). The pressure-responses of marine invertebrates: a psychophysical perspective. Zool. J. Linn. Soc. 80: $209-230$

Nelson, W. G. (1979). An analysis of structural pattern in an eelgrass (Zostera marina L.) amphipod community. J. exp. mar. Biol. Ecol. 39: 231-264
Novak, R. (1982). Spatial and seasonal distribution of the meiofauna in the seagrass Posidonia oceanica. Neth. $J$ Sea Res. 16: 380-388

Novak, R. (1984). A study in ultra-ecology: microorganisms on the seagrass Posidonia oceanica (L.) Delile. P.S.Z.N.I: Mar. Ecol. 5: 143-190

Pallares, R. E., Hall, M. A. (1974a). Analisis bioestadistico de la fauna de copepodos asociados a los bosques de Macrocystis pyrifera. Physis (Buenos Aires) 33: 275-319

Pallares, R. E., Hall, M. A. (1974b). Analisis bioestadistico de la fauna de copepodos asociados a los bosques de Macrocystis pyrifera. (Conclusion). Physis (Buenos Aires) 33 409-432

Palmer, M. A. (1984). Invertebrate drift: behavioural experiments with intertidal meiobenthos. Mar. Behav. Physiol 10: $235-253$

Palmer, M. A., Brandt, R. R. (1981). Tidal variation in sediment densities of marine benthic copepods. Mar. Ecol Prog. Ser. 4: 207-212

Palmer, M. A., Gust, G. (1985). Dispersal of meiofauna in a turbulent tidal creek. J. mar. Res. 43: 179-210

Penhale, P. A., Snith, W. O., Jr. (1977). Excretion of dissolved organic carbon by eelgrass (Zostera marina) and its epiphytes. Limnol. Oceanogr. 22: 400-407

Peterson, C. H., Summerson, H. C., Duncan, P. B. (1984). The influence of seagrass cover on population structure and individual growth rate of a suspension-feeding bivalve, Mercenaria mercenaria. J. mar. Res. 42: 123-138

Pollard, D. A. (1984). A review of ecological studies on seagrass-fish communities, with particular reference to recent studies in Australia. Aquat. Bot. 18: 3-42

Read, G. B. (1984). Persistence of infaunal polychaete zonation patterns on a sheltered, intertidal sand flat. N.Z. J] mar. Freshwat. Res. 18: 399-416

Reise, K. (1977). Predation pressure and community structure of an intertidal soft-bottom fauna. In: Keegan, B. F. Ceidigh, P. O., Boaden, P. J. S. (ed.) Biology of benthic organisms. Pergamon Press, Oxford, p. 513-519

Robertson, A. I., Howard, R. K. (1978). Diel trophic interactions between vertically-migrating zooplankton and their fish predators in an eelgrass community. Mar. Biol. 48: 207-213

Robichaux, D. M., Cohen, A. C., Reaka, M. L., Allen, D. (1981). Experiments with zooplankton on coral reefs, or, will the real demersal plankton please come up? P.S.Z.N.I: Mar. Ecol. 2: 77-94

Sogard, S. M. (1984). Utilization of meiofauna as a food source by a grassbed fish, the spotted dragonet Callionymus pauciradiatus. Mar. Ecol. Prog. Ser. 17: 183-191

Stoner, A. W. (1980). The role of seagrass biomass in the organization of benthic macrofaunal assemblages. Bull. mar. Sci. 24: $537-551$

Stoner, A. W. (1983). Distributional ecology of amphipods and tanaidaceans associated with three sea grass species. J. Crust. Biol. 3: 505-518

Summerson, H. C., Peterson, C. H. (1984). Role of predation in organizing benthic communities of a temperate-zone seagrass bed. Mar. Ecol. Prog. Ser. 15: 63-77

Thistle, D., Reidenauer, J. A., Findlay, R. H., Waldo, R. (1984). An experimental investigation of enhanced harpacticoid (Copepoda) abundances around isolated seagrass shoots. Oecologia (Berl.) 63: 295-299

Wieser, W. (1952). Investigations on the microfauna inhabiting seaweeds on rocky coasts. IV. Studies on the vertical distribution of the fauna inhabiting seaweeds below the Plymouth Laboratory. J. mar. biol. Ass. U.K. 31: 145-174 